\title{
A HÁZÉPÍTÉSEK (ANTI)SZOCIÁLIS TÁMOGATÁSÁNAK KRÓNIKÁJA
}

\author{
LENGYEL IMRE
}

\author{
„Felépült végül a házam, na jó \\ Kastélynak éppenség nem \\ mondhato \\ De kényelmes szék áll a tv \\ elótt \\ Vén vagyok, akár a föld"
}

(Bródy János)

A lakásépítésról és -gazdálkodásról szóló vita szinte egyidốs magával a lakással, a téma szakirodalma könyvtárnyira rúg, minden társadalomtudományi diszciplína mûvelối többször megírták ,,megváltó” javaslataikat és azok ellenkezôjét is. ${ }^{1}$ Ebbe a darázsfészekbe belenyúlni csak a tudatlanok bátorságával, avagy az elhivatottak eszelôsségével lehet. Mivel remélhetóleg egyik csoportba sem tartozom, a fullánkokat elkerülendỏ jelen dolgozatban csak egy szúk témát, a lakásépitésekhez és -vásárlásokhoz adott pénzbeli szociális támogatások és a lakossági hitelpolitika 1990-ig érvényes magyarországi gyakorlatának néhány olyan elemét és következményét vizsgálom, amelyek területi, településtípusonkénti sajátosságokat hordoznak. A téma nemcsak önmagáért érdekes, mivel meggyôzôdésem, hogy a lakásépítés a ,,szocialista rendszer" egyik állatorvosi lova, amelyen az elmúlt 40 év minden betegségének a tünete megfigyelhetô.

A lakás különleges áru, mind kereslete, mind kínálata eltérô sajátosságokat hordoz a közönséges árukéhoz képest. ${ }^{2}$ Egyik legfontosabb jellegzetessége az, hogy elvileg sem korlátlanul újjátermelhetô jószág, a fekvése (térbeli elhelyezkedése) sokszor fontosabb, mint felszereltsége és nagysága, avagy építésének költsége. Értéke az élettartama alatt - környezetének változásától függốen - akár többször is jelentôsen megváltozhat (ellenkezố irányokban is). A lakás legalább annyira beruházási jószág, mint fogyasztási cikk, valamint tartós kiegészítô jövedelem forrása is lehet. Egy lakás még a fejlett országokban is nagy értékủ, megszerzése az emberek többsége számára csupán folyó megtakarításból elképzelhetetlen, így fontos szerepük van a pénzügyi közvetítổ intézményeknek és az állami támogatásnak is. A lakás azért is különleges áru, mert akár akarjuk, akár nem, azt éghajlatunkon célszerü ,,fogyasztanunk”, valahol kell laknunk (vásárolt, bérelt, szuilổi stb. lakásban, avagy híd alatt hidalhatjuk át lakásproblémáinkat).

Az állam és a helyi önkormányzatok többféleképp ösztönözhetik, segíthetik közvetlenül vagy közvetve a magánerổs lakásépítést és -vásárlást: közmúvesített telket árulhatnak olcsón (vagy adhatnakingyen), adókedvezményt és kedvezményes kölcsönöket nyújthatnak, vissza nem térítendô, szociális jellegứ pénzbeli támogatásokat adhatnak, dotálhatják az építôanyagok árát stb. Számtalan módja van annak, hogy egy közösség elôsegítse és ösztönözze tagjainak sajắt pénzügyi forrásból történổ otthonteremtését. Dolgozatomban csak két szükebb területtel foglalkozom részletesen: a lakásépítéshez és -vásárláshoz gyermekenként adott szociálpolitikai támogatás alakulásával, valamint a kedvezményes hitelek összegének és feltételeinek változásával (az önrészesedés mértéke, a visszafizetés idổtartama, a kamatláb nagysága stb.). Teszem ezt fổleg 
abból a szempontból, hogy milyen regionális és település-típusonkénti jellegzetességek figyelhetốk meg. A lakáskérdés egyéb szorosan kapcsolódó kérdéseire, az állami forrásokból történố lakásépítésekre, a lakásbérletekre és támogatásukra, illetve az állami bérlakások magánkézbe adásának területi sajátosságaira nem, vagy csak érintőlegesen térek ki.

\section{A gyermekenként adott (szoci)álpolitikai támogatás}

A gyermekek után járó szociálpolitikai támogatást 1971-ben vezették be, és 1982-ig a lakások építési módja szerint változott az egy gyermek után elszámolható összeg. A lakásokat alapvetỏen két csoportra bontották, társasházra és családi házra, csoportokon belül is megkülönböztetéseket téve. ${ }^{3}$ Társasházban levỏ lakás vásárlásánál (építésénél) a vizsgált idổszakban mindig járt a szociálpolitikai támogatás, míg családi ház esetében csak 1981-tốl, illetve 1983-tól. Gyereknek minôsült a 16 évesnél nem idôsebb, egy háztartásban élố saját, nevelt vagy örökbefogadott fiatal, illetve nappali tagozatra járó olyan tanuló, aki még nem töltötte be a 25 . évét.

1971 és 1980 között telepszerú többszintes társasházban (amely az OTP-n kívül épülhetett lakásépítổ szövetkezet, termelổ vállalat stb. szervezésében), OTP beruházású (egyedi társasház is lehetett), vagy tanácsi értékesítésủ lakás vásárlása esetén meglevô ( 2 fổig vállalható) gyermekenként 30 ezer, egyéb szervezésú egyedi társasháznál 20 ezer forint volt a szociálpolitikai kedvezmény (1. táblázat). Ebben az időszakban családiház-épitéshez nem adtak ilyen támogatást.

1. TÁBLÁZAT

A gyermekenként adott szociálpolitikai támogatás 1971 és 1984 között (ezer forint/gyermek)

\begin{tabular}{lcccc}
\hline & $1971-1980$ & $1981-1982$ & 1983 & 1984 \\
\hline Telepszerú többszintes társasház & 30 & 30 & 30 & 40 \\
OTP beruházású társasház & 30 & 30 & 30 & 40 \\
Tanácsi értékesítésú lakás & 30 & 30 & 30 & 40 \\
Egyedi társasház & 20 & 20 & 30 & 40 \\
Csoportos családi ház & - & 20 & 30 & 40 \\
Hagyományos családi ház & - & - & 30 & 40 \\
\hline
\end{tabular}

Késốbb a helyzet annyiban változott, hogy 1981-ben és 1982-ben már a csoportosnak minősített családi házaknál (20 ezer forintot gyermekenként), 1983-tól pedig a hagyományos családi házaknál is igénybe lehetett venni az immár egységes, az építkezési formáktól független szociálpolitikai kedvezményt.

1985-tôl jelentốsen megváltoztak a szociálpolitikai támogatás feltételei, nemcsak egységesítették a különbözổ lakástípusok szerinti kedvezményeket, hanem egy másik viszonyítási rendszert, a gyerekek számát vették alapul. A támogatás igénylésekor a meglevổ gyerekszámtól függổen eltérổ összegeket kaphattak az építkezök (2. táblázat). Míg 1985-ben a harmadik gyerek már , , kétszer annyit ért”, mint idôsebb testvérei, a késốbbiekben a második, méginkább a harmadik gyerek támogatásának összege növekedett egyre nagyobb ütemben, míg az elsố gye- 
2. TÁBLÁZAT

A gyermekek után adott szociálpolitikai támogatás 1985 és 1990 között (ezer forint/gyermek)

\begin{tabular}{lcccc}
\hline & 1985 & 1986 & $1987-1988$ & $1989-1990$ \\
\hline Elsó gyermek & 40 & 40 & 40 & 50 \\
Második gyermek & 40 & 65 & 65 & 150 \\
Harmadik gyermek & 80 & 125 & 125 & 400 \\
További gyermek & 40 & 40 & 40 & 100 \\
Utólag született & 40 & 40 & 40 & 50 \\
\hline
\end{tabular}

reké 40-rốl csupán 50 ezer forintra növekedett. 1989-ben az elsổ gyerek után 50, a második után 150, míg a harmadik gyerek után már 400 ezer forint járt.

Úgy tûnik, hogy a , háromgyermekes családmodell” az ideális, mert a további gyerekek után járó összeg nem számottevố. Még 1987-ben is 40 ezer forint volt a támogatás a negyedik és további gyerekek után, amely összeg csupán 1989-ben nổtt 100 ezer forintra. ,,Felelốtlen” volt az az anya is, aki a lakásvásárlás után szülte meg harmadik gyermekét, mivel akkor 400 ezer helyett már csak 50 ezer forint járt. A lakásvásárláskor gyermektelen fiatal házaspároknak (egyikük sem töltötte be a 35 . évét) legfeljebb két gyerekre lehetett megelốlegezni a kedvezményt, ha több született, akkor alacsonyabb összegú utólagos támogatást kaptak. Egy megelổegezett gyereknek 3 éven, kettônek 6 éven belül kellett megszületnie.

A szociálpolitikai támogatások idốbeli változásai miatt kialakuló különbözeteket 1990-ig el lehetett számolni. Azaz lakáscsere (új lakás vásárlása) esetén az éppen aktuális összegbốl le kellett vonni az egyszer már igénybe vett támogatásokat, egyedül az így nyert különbözetre lehetett jogot formálni. A különbözet utólagos elszámolása 1990-ben megszúnt, jelenleg csak az elsổ lakás vásárlásához jár az éppen aktuális összeg. Tapasztalataim szerint erốteljes mobilizáló hatása volt az utólagos elszámolásnak, mert ahol született egy harmadik gyerek, vagy még nem vették igénybe a kedvezményt, ott 1988 után (amikor az összeg látványosan megnốtt) a legrövidebb idôn belül költöztek, vagy építkezésbe fogtak, hogy ,tốkésítsék” a támogatást (pontosabban a különbözetet). 1989 ôszén villámgyorsan elterjedt a hír is, hogy a különbözet utólagos elszámolása megszúnik. Elindult egy újabb roham a lakások iránt, ami az amúgyis magas ingatlanárakat a fellegekbe emelte.

Lehetôség volt az eltartottak utáni szociálpolitikai támogatás igénylésére is, amely 1984-ig 20, a késóbbiekben 30 ezer forintot tett ki. Eltartottnak minôsült az egy háztartásban éló alacsony nyugdíjjal rendelkezó (avagy legalább 67\%-os rokkant) hozzátartozó, az olyan háztartásbeli házastárs, aki legalább 2 gyermeket nevel stb. A szociálpolitikai kedvezményeket csak a vételár, az építési költségek, avagy a hiteltartozás kiegyenlítésére lehetett felhasználni, azaz a pénzügyi intézet ezt az összeget leîrta a hitelekból, készpénzt nem adott (pl. ha az utólagos kedvezmény nagyobb, mint a még fennálló hitel, akkor csak a hitel nagyságáig jár ez a szociálpolitikai támogatás).

A szociálpolitikai támogatás egyik legfontosabb jellemzóje, hogy csak az OTP által értékesített (új vagy visszavásárolt), illetve az OTP pénzügyi közremúködésével (kölcsönével) épített lakás esetén lehetett igénybe venni (a tanácsok által értékesített lakásoknál, illetve az általuk 
kijelölt vevốk esetében is az OTP volt a pénzügyi bonyolító). 1983 után a kölcsön nélkül épülố családi házaknál a lakhatási engedély felmutatásával lehetett ezt a kedvezményt igényelni. A pénzügyi kormányzat az OTP monopolhelyzetére támaszkodva, azt fenntartva és megerôsítve próbálta kézben tartani a ,,lakáspiacot', nehéz helyzetbe hozva a magánforgalomban értékesített lakások vásárlóit (legalábbis a gyerekeseket) ${ }^{4}$ A helyi tanácsok (az OTP lebonyolításában) és 1985 után a takarékszövetkezetek is nyújthattak kedvezményes kölcsönöket, amihez szociálpolitikai támogatás is járt.

Milyen területi jellegzetességeket, különbségeket hordoznak a gyermekek után járó szociálpolitikai támogatások? Legfontosabbnak az túnik, hogy a korszerútlennek (avagy a gazdagok luxusának?) minôsített családiház-építések után 1983-ig nem járt támogatás (egy kalap alá véve a falusi vályogházat a rózsadombi villával), így rosszul jártak azon térségek és települések lakosai, ahol a magánerôs házépítés dominált. Az 1971-1982 között épített lakásoknak országosan majdnem fele volt magánerổs családi ház, és ez területileg, településtípusonként egyenlốtlenül oszlott el. Budapesten és a nagyobb városokban, a nehézipari centrumokban elenyészô, a kisebb városokban már meghatározó arányban épültek családi házak, míg a községekben és falvakban másra szinte nem is volt lehetốség (a részletes adatokra késốbb térünk ki). Így a szociálpolitikai támogatás csak a városi lakosság egy részének lakásgondjain könnyített, a községekben, falvakban építkezốk elestek ezektôl az összegektõl, holott 1971 és 1982 között itt készült a magánerốbôl épített lakások 54.1\%-a. A lakásgondokkal küszködő falusiak vagy a hátrányokkal sújtott családi házat építették (a többszintes lakóházak száma elenyészó), vagy elköltöztek. A községekben élố családok négyötöde mindmáig tisztán magánerổbốl jutott lakáshoz, mintegy $10 \%$-uk állami és szolgálati lakásban, a többi magánbérletben vagy eltartottként él. ${ }^{5}$ Nehezen becsülhetố az is, hogy hány olyan fiatalkorú és eltartott élt ezekben a családokban, akik kipotyogtak az igencsak lyukas ,,szociálpolitikai hálóból”, mekkora az utánuk járó elmaradt összeg, az elhúzódó beruházásokból mi maradt befejezetlenül, mirôl kellett lemondaniuk, mennyit kellett dolgozniuk ezeknek az embereknek, hogy pótolják az egyenlốtlen támogatási rendszer miatt kiesổ anyagi javakat. ${ }^{6}$

Az elosztásnál megfigyelhetố törvényszerüséget másképpen meg fogalmazva, a szociálpolitikai támogatás a városokban és kiemelt településeken folyó többszintes lakóházak építését segítette elố, és bizonyos mértékig lehetôvé tette, hogy a nagy költségekkel épített és korszerünek kikiáltott panel, blokk stb. falazatú lakásokat a fiatalok is meg tudják venni. Ezáltal a költségvetésbốl támogatta a pénzügyi kormányzat a házgyárak és a nagy építőipari szervezetek fennmaradását, áldását adva az egekbe szökõ költségekre és az igen alacsony minốségi színvonalú munkára, mivel a szociálpolitikai támogatás végül is az építóipar ,,kasszáját” gyarapította. ${ }^{7} \mathrm{Az}$ állami építőipar (s rajta keresztül a lakásépítésekben érdekelt magyar háttéripar) az alkuk során el tudta fogadtatni emelkedô költségeit, hiába volt az általuk épített lakások ára elvileg maximált. Állami intézkedések sokasága is elốsegítette a fizetốképes kereslet fennmaradását, a lakosság fokozottabb megterhelése mellett a költségvetés is növelte burkolt dotációit (1982-ig elég nyîltan a többszintes lakóházak építésében monopolhelyzetben levố állami építőiparnak címezve), ezáltal is gerjesztve az inflációt, és növelve az államháztartás deficitjét (a több pénz mögött nem volt több lakás).

A szociálpolitikai támogatás odaítélésénél nem vették figyelembe a családok szociális helyzetét, jövedelmi viszonyát, szinte mindenféle mérlegelés nélkül mindenkinek járt, ha új lakást 
vett, vagy épített. Mivel ebbốl a kedvezményból a lakosság nagy része, mintegy fele kimaradt (többsége falvakban élổ kis jövedelmũ család), ezért 1983-ig nem volt nivelláló jellegú ez a támogatás, sổt az egyenlốtlenségeket tovább növelte, mert az amúgy is kedvezốbb helyzetben lévốk esélyeit javította. Ezért a ,szociálpolitikai” jelzổ félrevezetố, mert ez a redisztribúció a közelmúltig semmiképpen sem minősithetố szociálisnak, legfeljebb politikainak. ${ }^{8}$ Igaz, létezett olyan kikötés, hogy csak az veheti igénybe a kedvezményeket, akinek lakásigénye méltányolható. Azaz, ha az együtt költözô családtagok lakásigénye a normaként meghatározott felsố határt (amelyet egy 1971-es rendelet írt elö) legfeljebb egy lakószobával haladja meg, és a lakás építési költsége, eladási ára egy hasonló lakás elổzó évi megyei (fôvárosi) átlagköltségét legfeljebb két és félszeresen múlja felül. Mindkét feltételnél gyerekjáték a kiskapukat megtalálni, így alig épült olyan lakás, amelyik nem kapott méltányossági alapon támogatást.

1989-cel bezárólag az idốben eltérô összegũ szociálpolitikai támogatások különbözeteit mint azt említettük - igénybe lehetett venni. De ez az utólagos elszámolás is fóleg a többszintes lakóházakban élốknek (így elsốsorban a városi lakosoknak) kedvezett, mivel csak a ,,szokásosnak" mondható cserét kellett lebonyolítani a családi létszám növekedése, avagy az anyagiak összeszedése után. A családi házakat, amelyek többsége egy egész életre szól, egy-két szobával nagyobbra nem szokás cserélgetni (legfeljebb építenek hozzá), így a kedvezmények különbözeteit falvakban ritkán igényelték.

Megjegyezzük, hogy az utóbbi években a nem városi településeken az üresen álló családi háznak a tanács kijelölése alapján a tanácsi ingatlanközvetítô szervezet közreműködésével történố vásárlása esetén is igényelhetô ez a vissza nem térítendô állami támogatás. Ezáltal területileg ott is érvényesülhetnek szociális szempontok, ahol alig van állami bérlakás. (Igaz, hogy kevés ilyen akcióra került sor a tanácsok nehéz anyagi helyzete miatt.)

A szociálpolitikai támogatás változásait 1971 és 1990 között áttekintve, egyik fontos fordulópontnak tûnik 1982, a családi házak diszpreferenciájának megszüntetése. Másik lényeges új elem, hogy 1990-tól csak egy alkalommal lehet igényelni ezt a támogatást. Azon túl, hogy ez az intézkedés csökkenti az állami költségvetés kiadásait, jelentốsen megnehezítheti a többgyermekes családok költözését a megnövekedett létszámnak megfelelổ lakásba. Ugyanis a családok többsége elsố saját lakása elốtt általában nem vállalja a harmadik gyereket, az utólag született után pedig kis összegû̉ a támogatás, ami nem segíti elő nagycsaládosoknál a megfelelő méretũ lakáshoz jutást. Ezzel részben összefüggésben a lakásmobilitás visszaesése várható, elsôsorban az olcsóbb, kisebb lakások kínálata csökken, így a fiata házasok számára a szociálpolitikai kedvezmény csupán , pénz az ablakban”, mivel öröklakís vásárlására alig van esélyük. ${ }^{9}$

Az 1985-ben életbe lépett, a gyerekek számától függố tá mogatás reálértéke, aránya a lakások árában 1980-hoz képest három meglevố gyerek esetén szinten maradt (sốt kissé növekedett is), két gyereknél kismértékben csökkent, míg egy gyereknél jelentéktelenné vált. Mindvégig változatlan maradt a bemutatott szociálpolitikai rendszerben az, hogy a szociális helyzetet és jövedelmi viszonyokat nem vették alapul a támogatások odaítélésekor.

\section{A hosszúlejáratú kedvezményes lakáskölcsönök}

A magánerổs lakásépítés és -vásárlás állami támogatásának másik eszköze Magyarországon a hosszúlejáratú kedvezményes hitelek nyújtása. Ezeknek a hiteleknek a reálkamatlába mindig negatív volt, a különbözetet, azaz a veszteséget az OTP-nek (illetve az utóbbi években a lakás- 
szövetkezeteknek) az állami költségvetés utalta ${ }^{10} \mathrm{~A}$ kedvezményes hitel minden lakásépítố és -vásárló számára - érthetốen - roppant elônyös volt, ezért minél nagyob összeget szerettek volna felvenni. Két korlátot, a kölcsönök összegének felsô határát és az elvárt önrészesedés mértékét, mindvégig elốrtak.

1960 és 1980 között, többszintes lakóházban levố lakás vásárlásánál nem hoztak hátrányos megkülönböztetéseket a települések státusa szerint (mivel ilyenek falvakban elvétve épültek, azokat is szinte kizárólag az állami építôipar építette). Az igényelhetô összeg 20 év alatt 120 ezer forintról 320 ezer forintra változott, fóleg 1973 után volt erốteljes a növekedés. Ekkor zajlott a házgyárak és lakótelepek , ,utóvirágzása”, az emelkedố költségeket részben ezekkel a hitelekkel hárították a lakosságra, ezzel is fenntartva a fizetốképes keresletet (3. táblázat).

3. TÁBLÁZAT

A lakásépitéshez és -vásárláshoz igénybe vehetố kedvezményes hitelek felsố korlátja 1960 és 1980 között

(ezer Ft)

\begin{tabular}{lccccc}
\hline & $\begin{array}{c}\text { Többszintes } \\
\text { lakóházbeli } \\
\text { lakás }\end{array}$ & Budapesten & $\begin{array}{c}\text { városban, } \\
\text { kiemelt } \\
\text { településeken }\end{array}$ & $\begin{array}{c}\text { egyéb } \\
\text { településeken }\end{array}$ & $\begin{array}{c}\text { állami vállalat } \\
\text { munkása, vagy } \\
\text { több gyermekes }\end{array}$ \\
\hline $1960-1970$ & 120 & 80 & 70 & 50 & - \\
$1971-1972$ & 150 & 100 & 80 & 70 & - \\
1973 & 250 & 100 & 80 & 70 & - \\
$1974-1975$ & 250 & 100 & 80 & 70 & 100 \\
$1976-1977$ & 300 & 120 & 100 & 90 & 140 \\
$1978-1979^{*}$ & 320 & 140 & 120 & 110 & 160 \\
1980 & 320 & 180 & 160 & 150 & 200 \\
\hline
\end{tabular}

*1979. augusztus 1-tól változott

Hagyományos családi házaknál 1960 és 1980 között pontosan kidolgozott hierarchián alapuló értékek léteztek. Három plusz egy kategóriát alkottak: Budapest, városok és kiemelt települések, egyéb települések. Ezekhez csatlakoztak újabb kategóriát alkotva 1974-ben, településhelytól függetlenül, az állami vállalatok munkásai és a többgyermekes családok. 1970 után, egészen 1980-ig a fốváros és a többi város között 20, utóbbiak és az egyéb települések között 10 ezer forint volt a ,,távolságtartó” különbség. Az állami vállalatok munkásai és a többgyermekesek által felvehetó hitelek még a kiemelt fốvárosi értéket is meghaladták.

A felújitáshoz, toldaléképítéshezés lakásmegosztáshoz 1974-ig egységesen 45 ezer forint kedvezményes hitelt lehetett felvenni. Ezt követôen két csoportot képeztek: a fớvárosban, városokban és kiemelt településeken 70, az egyéb településeken 60 ezer forintot igényelhettek (1979-ben már 100, illetve 90 ezer forintot). Viszont a lakáskorszerüsitéseknél nem tettek megkülönböztetést települések szerint, 1971 után 30, 1974-tốl 40 és 1979-tốl 70 ezer forintot lehetett kölcsönként fölvenni.

A maximálisan felvehetố hitelösszegek változásából két alapvetố tendencia bontakozik ki: egyrészt a többszintes lakóházak és családi házak kölcsöneinek nagysága között mindvégig 
mintegy kétszeres volt a különbség. Másrészt a települések státusa szerint a családi házakra felvehetổ kölcsönök is merev sorrendet követtek, ami csak részben vezethetố vissza a telekárak különbözỗségeire. Kevéssé magyarázható az állami vállalatok munkásainak kiemelése - talán ideológiai szempontok alapján döntöttek. Falvakban, városhiányos térségekben, ahol a mezốgazdasági tsz-ek, ipari és szolgáltató szövetkezetek tevékenysége a meghatározó, állami vállalatoknál levổ munkahely csak elvétve található, így ez a megkülönböztetés is nyilvánvalóan területi hátrányokat hozott. Nem volt mindegy, hogy a városba ingázó falusiak milyen munkahelyre jártak, nevezetesen szövetkezeti avagy állami céghez. Az állami vállalat amúgy is több fizetést nyújtott és a nagyobb kölcsön miatt az építkezés is könnyebb volt (nagyobb volt az esély munkáltatói támogatásra). Ez a kiemelt hitelnyújtás egy ellentmondást próbált feloldani, mivel a vizsgálatok szerint az alacsony jövedelmü fizikai dolgozók (betanított- és segédmunkások) jutottak a legnehezebben és a legnagyobb anyagi áldozatokkal lakáshoz, általában rákényszerültek a családiház-építésre. ${ }^{11}$ Viszont az alacsonyabb jövedelmủeknek csak egy részét, az állami vállalatok munkásait támogatták, ami a szövetkezetek dolgozóit, fớleg az agrártérségekben élốket, hátrányosan érintette.

A hitelekkel járó kedvezmények megoszlása igen differenciált képet mutat. 1960 és 1980 között az önrészesedés mértéke, illetve ellentettje, a kölcsönök részesedése az építési költségekbổl, lakásárból rendkívül tág határok között, 50 és $90 \%$, változott a különbözô értékek és lobbyk hatására. Hasonlóan változatosan alakult a kamatlábak nagysága is, $1 \%$ és 3,5\% közötti értéket felvéve. A maximális törlesztési idố 25 és 35 év között változhatott. A hitelek kedvezményeinek differenciált feltételrendszerérổ hủ képet nyújt az 1981-ben érvényes hitelpolitika, amelynek elemei a hetvenes évekhez képest alig változtak. *

Az 1981-82-ben felvehetổ lakossági lakásépítési (-vásárlási) kölcsönöket az építési forma szerint különböztették meg:

a.) Telepszerũ többszintes lakóházban levổ lakás vásárlása esetén kiemelt vagy általános hiteleket nyújtottak. Kiemelt hitelre jogosult az állami vállalat munkása, vagy lakásépítô szövetkezet szervezésében épülô társasháznál a bérbốl, fizetésbổ élô (szövetkezeti tag és nyugdíjas is). A kiemelt hitel felsố határa 320 ezer forint és $70 \%$ vagy $75 \%$ a kölcsön mértéke (azaz 30\% vagy $25 \%$ önrészesedés), a kamat $1 \%$ és 35 év a maximális törlesztési idô. Kiemelt hitelt kaphatott a tanács által kijelölt, az elốzó körbe tartozó vevõ is, ha magánberuházásban készült lakást vásárolt: 320 ezer forint vagy $75 \%, 2 \%$-os kamatra 35 évig. Ha a munkáltatói támogatás a nettó vételár legalább $10 \%$-át tette ki, akkor többszintes lakóházépítés (vásárlás) esetén ez a hitelnyújtás is kiemeltnek minôsült. Általânos (nem kiemelt) hitelnyújtás esetén a feltételek kedvezốtlenebbek: 270 ezer forint vagy $75 \%, 2 \%$-os kamat és 35 év. Ha a vevổ szabad foglalkozású vagy önálló, akkor a kölcsön mértéke 70\% (a többi feltétel megegyezik az elốbbivel).

b.) Egyedi többszintes és csoportos korszerú lakóház esetén lakóegységenként 230 ezer forint vagy $70 \%$ a felsổ határ, amelyet $3 \%$-os kamatra 30 éves törlesztésre adtak. A hitelösszeg felsố határát az OTP megyei (kerületi) igazgatója egyedi esetekben saját hatáskörben 30-40 ezer forinttal felemelhette. Munkáltatói támogatás esetén: 320 ezer forint vagy 60\%,3\%-os kamat és 30 év.

c.) A hagyományos családiház-építés hitelezésekor a településeket két csoportra osztották. Városokban és kiemelt településeken a kölcsönök jellemzỏi: 200 ezer forint vagy $60 \%$, amit 3,5\% kamatra 25 évi törlesztésre adtak (többgyermekeseknek $2 \%$ és 30 év). Egyéb települése- 
ken a hitel 160 ezer forint vagy $50 \%$, amely itt is 3,5\% kamat mellett 25 évre szólt (többgyermekeseknek $2 \%$ és 30 év). Ha az ajánlott típustervek alapján építkeztek, akkor 10\%-kal megnốtt a kölcsön mértéke.

d.) Lakások felújitására városokban és kiemelt településeken a kölcsön 100 ezer forint vagy $75 \%, 2 \%$ és 15 év. Egyéb településeken 90 ezer forint vagy $75 \%$, ugyanolyan kamat és törlesztési feltételek mellett. 1982-ben a nagyméretü lakások múszaki megosztását, a nem lakás céljára szolgáló helyiségek lakássá történô alakítását is differenciáltan szabályozták. Városokban a kölcsön 100 ezer forint vagy $75 \%$, míg egyéb településeken 90 ezer forint vagy $75 \%$ (mindkét esetben 15 évre és 3\%-os kamatra).

A fentiekben bemutatott szabályozás tükrözi az 1982-es lakásreform elốtti kaotikus állapotokat. Igen bonyolult módon szabályozták a hitelnyújtást, keményen folyt a lobbyzás az előnyösebb minốsítésekért (nem érte meg szabad foglalkozásúnak vagy önállónak lenni, a szerzốdéskötés elôtt bizonyos idốvel célszerú volt ,,vattaembert” keresô állami vállalatnál tartani a munkakönyvet). A túlszabályozást az is jelzi, hogy az elốbbi ismertetônk koránsem teljes, nem foglalkoztunk a tanácsi (szövetkezeti) értékesítésú lakásokkal (ahol a vételár $40 \%$-át az állam állta, a fennmaradó összegnél $90 \%$ a kölcsön felsổ határa, 1\% a kamat és 35 év a törlesztési idố), az ifjúsági takarékbetétek után járó külön kölcsönnel, a munkáltatói támogatásokkal (többek között állami vállalatok munkásai városokban többszintes társasházi lakásokat kedvezménnyel kaphattak, ha a vállalatnál hosszabb idốre lekötötték magukat), azzal, hogy a törlesztések linearitása megszûnt, progresszív módon is lehetett fizetni stb. Vázlatos bemutatásunk alapján is egyértelmú azonban, hogy a rendeletalkotók ,,múvészi fokon” bonyolították mesterségüket, az akkori hatalomhoz kötổoó különbözổ részérdekek eredményesen harcoltak a kedvezményekért.

Komoly területi hátrányokat okozott az, hogy a családiház-építéshez fele akkora összegü hitelt lehetett csak felvenni, mint többszintes társasházi lakásra, nagyobb önrészesedés kikötése mellett, magasabb kamatra és rövidebb törlesztési idốvel. Ráadásul a városokhoz képest az egyéb településeken még ez az összeg is csökkent és az elvárt önrészesedés is megnổtt. Az adatokból egyértelmúen kitetszik, hogy mindegyik szabályozási paraméternél a városi lakókat támogatták, fốleg a többszintes házban levô lakások vásárlóit részesítették állami támogatásban (ezáltal is csökkentve a tanácsi bérlakások szerzésére irányuló társadalmi nyomást), akik többsége amúgy is magasabb jövedelmú és szakképzettebb rétegekbốl került ki.

A kedvezményes hitelnyújtás szabályozása 1983-tól változott, némileg egyszerũsödött és 1988-ig nagyjából azonos elveken nyugodott (4. táblázat). A lakásépítésnél csak a többszintes társasházat és a családi házat különböztették meg a hitelnyujjtás szempontjából, és a kölcsönök felsổ határát a család létszámától tették függốvé, valamint megszünt a településtípusok szerinti differenciálás. 1983 és 1987 között a többszintes társasházi lakásra mindegyik kategóriában 60 ezer forinttal többet lehetett felvenni, mint családiház-építéskor. Ez a megkülönböztetés csak 1988-ban szûnt meg, akkortól a lakóegység építését (vásárlását) támogatják a ,,korszerứ” minôsítéstốl, az építés helyétốl, formájától és az építō szervezettôl függetlenül. A kölcsönök legmagasabb mértéke $70 \%$, amit a gyerekek után járó szociálpolitikai támogatással csökkentett építési költség (vásárlási ár) alapján kell kiszámolni. A leghosszabb törlesztési idố egységesen 35 év és a kamat $3 \%$. 
Lengyel Imre: A házépitések (anti)szociális támogatásának krónikája.

Tér és Társadalom, 5. 1991. 1. 1-22. p.

\section{TÁBLÁZAT}
A lakásépitéshez és -vásárláshoz felvehetố kedvezményes hitelek maximális aránya (\%) és felsố határa 1983 és 1988 között (ezer forint)

\begin{tabular}{lcccccc}
\hline & \multicolumn{2}{c}{$1983-1985$} & \multicolumn{2}{c}{ 1986-1987 } & 1988 \\
\cline { 2 - 7 } & $\begin{array}{c}\text { Többszintes } \\
\text { társasház }\end{array}$ & $\begin{array}{c}\text { Családi } \\
\text { ház }\end{array}$ & $\begin{array}{c}\text { Többszintes } \\
\text { társasház }\end{array}$ & $\begin{array}{c}\text { Családi } \\
\text { ház }\end{array}$ & $\begin{array}{c}\text { Összes } \\
\text { lakás }\end{array}$ \\
\hline Legnagyobb arány (\%) & 70 & 60 & 70 & 70 & 70 \\
\hline \multirow{4}{*}{ család- } & $1-2$ fón & 320 & 260 & 320 & 260 & 320 \\
nagyság & $5-4$ fó̉ & 360 & 300 & 380 & 320 & 380 \\
& 6 fốn fớ & 400 & 340 & 440 & 380 & 480 \\
& & 440 & 380 & 500 & 440 & 540 \\
\hline
\end{tabular}

A kedvezményes kölcsönök kiegészítésére 1983-tôl bankkölcsönöket lehet felvenni, amelyek nagyságát a bank az ügyfél fizetôképességének ismeretében dönti el. Korábban az általánosan felvehetố, a kedvezményes összegen felüli pénzintézeti építési kölcsönök nem léteztek. A leghosszabb törlesztési idổ a bankkölcsönnél 15 év, a kamat 1985-ig 8\%, azt követően csak 100 ezer forintig $8 \%$ (1988-ban már ez is $12 \%$ ), az efölötti összegeknél magasabb. Másmilyen külön kölcsönöket is fel lehetett venni. Az ifjúsági takarékbetétek után 3\%-os volt a kamatozás, a többi külön kölcsön (elôtörlesztési, lakástakarékossági stb.) kamata általában a bankkölcsönével egyezett meg. Munkáltatói támogatás esetén a saját forrás minimális mértéke többszintes társasházi lakásnál 10\%, családi háznál 20\%. Megemlítjük, hogy az árvíz és belvíz által megrongált házak újjáépítésére kamatmentes kölcsönöket adtak, illetve az említetteken kívül még több akció is lezajlott, pl. a pedagógusok kedvezményes lakásépítése, az állami gazdaságok területén lévô elavult lakások felszámolása, az áttelepülố szénbányászati dolgozók lakásellátása, fiatal házasok hároméves programja stb.

1989-ben újra megváltoztak a lakásépítéshez (vásárláshoz) nyújtott kölcsönök feltételei és a támogatások kiszámításának módozatai. A kedvezményes kölcsönöket 25 évre adják 18,5\% kamat mellett (legalábbis a dolgozat lezárásakor). A kevezmény nem a kamatterhek korábbiakban megszokott egyoldalú átvállalását jelenti, hanem azt, hogy a havi részletek törlesztéséhez az állam a törlesztés elsổ 15 évében támogatást nyújt. Általános esetben a támogatás a törlesztés elsô öt évében a havi törlesztỏrészlet 30\% -a, a következổ tíz évben $15 \%$-a, de az esedékes kamat összegét nem haladhatja meg (azaz két korlátot írtak elố). A felvehetổ kölcsön nagyságát az ügyfél fizetốképessége határozza meg. Gyermekes családok kiemelt törlesztési támogatású kölcsönt vehetnek fel, amely egy gyermeknél maximum 300 ezer, két gyermeknél 400 ezer, három vagy több gyermeknél 500 ezer forint lehet, vagy a szociálpolitikai kedvezménnyel csökkentett építési költség (vásárlási ár) 70\%-a. Ennél a kedvezményes kölcsönnél a törlesztés elsố öt évében a támogatás a gyerekszámtól függően $40 \%, 70 \%$ vagy $80 \%$, de az esedékes kamat összegét itt sem haladhatja meg. A következỏ öt évben a kedvezmény az elsổ pentád százalékainak fele. Ha a kiemelt kölcsön nem elég, akkor az általános feltételeknek megfelelően lehet a hiányzókat felvenni, ha a bank is lát garanciát a visszafizetésre, a havi törlesztés általában a 
jövedelem harmadánál nem lehet nagyobb. A kamatterhek átvállalásának ez a rendszere azt jelenti, hogy a családalapítás utáni években 1-3\%-os kamattal kell törleszteni a kölcsönt (1\% a bank kezelési költsége).

A kedvezményes hitelek összegének emelkedése - miként a szociálpolitikai támogatásé is - részben azt a célt szolgálta, hogy az építỏipar át tudja hárítani az egyre nagyobb költségeket a lakosságra és az állami költségvetésre (a kamattámogatással). Másrészt a 15 éves lakásépítési programok idôarányos részét az állami forrásból történô lakásépítés nem tudta teljesíteni, rendre elmaradt a tervektốl, ezért a lakáshiány miatti feszültségeket csak a magánerôs építkezések, vásárlások ösztönzésével lehetett enyhíteni. Mivel a bérek nem tartalmazzák a lakásköltségeket, ezért a hitelek összegét emelni kellett, és szép lassan a családiház-építéseket is megtürték. A társasházi lakásokhoz képest a felvehetố hitel kisebb volt ugyan, de az utak burkolására, a víz-, a gáz- a közcsatorna-vezeték kiépítésére külön kölcsönöket lehetett igényelni (nyilván csak ott, ahol ezek létrehozására egyáltalán megvolt a lehetổség). Ezekre a külön kölcsönökre nagy szükség volt, mivel a lakossági infrastruktúra kiépítésére csak minimális állami forrásokat szántak, döntổ részét lakossági pénzekbốl, társulásokkal lehetett megvalósítani. Az mindenesetre elgondolkoztató, hogy a központi költségvetésnek jóval kevesebbe került egy családi ház, mint egy társasházi lakás, holott átlagos alapterülete majdnem kétszer nagyobb.

Ha az volt az egyik cél a családi házak területi diszpreferálásával, hogy a falvakban lakó és ingázó ipari munkások városokba költözve kedvezốbb feltételek mellett is építkezzenek, akkor ez csak , ,csalfa remény" volt (a költözéstốl idegenkedổ munkások inkább a helyi tsz ipari melléküzemágában helyezkedtek el), amelyet egyéb rendeletek is meghiúsítottak (építkezési elốírások, letelepedési korlátozások, állami telkek visszafogott árusítása stb.). A kedvezốtlenebb támogatási feltételek nem az elköltözésre ösztönöztek, hanem fokozottabb önkizsákmányolással a szükséges anyagiak elổteremtésére (második gazdaság, kalákában építkezés stb.). Mivel a családi házakat általában nem vállalkozók építették, hanem maga a tulajdonos , ,hozta össze” szabad idejében, többé-kevésbé szakemberek segítségével, ezért praktikusabb volt a lakóhelyen, vagy ahhoz közel építeni, hogy ne kelljen messzire menni a szinte mindennapos robotban. A gyakran minden szakszerüséget nélkülözô építkezések mellett a diszpreferencia másik kedvezốtlen hatása a munkák idốbeli elhúzódása. Késốbbre maradnak a nélkülözhetố dolgok (melléképületek, kerítés, vakolás, járdák stb.). Idônként félig készülnek el a házak, nem tudják bevezetni a vizet (igy a fürdôszobát sem , ,kell' berendezni), a fũtésnél meg kell elégedni a szenes kályhával, a padlóra sem linóleum, sem parketta nem kerül, stb.

A hosszú lejáratú kedvezményes hiteleket és a gyerekek után felvehetố szociálpolitikai támogatást is - mint már említettük — csak az OTP (késóbb takarékszövetkezetek) közremüködésével értékesített lakások vásárlásakor, vagy új családi ház építésekor lehet igényelni, magánforgalomban vásárolt lakásnál nem. Az OTP, mint ingatlan-forgalmazással is foglalkozó szervezet, csak olyan használt lakásokat vesz meg, amelyek mû́szaki színvonala kifogástalan, és gond nélkül forgalmazható (ha a vásárló késốbb pereskedni találna rejtett hibára hivatkozva). A falvakban levố öreg, általában vályogból épült, de még elfogadható állapotban levố házakat nem veszi meg az OTP, ezáltal az esetleges vásárló nem kaphat sem szociálpolitikai támogatást, sem kedvezményes hosszú lejáratú hitelt. Így ezeket az egyébként olcsó házakat csak magánforgalomban, készpénzért lehet megvenni, amire a kis jövedelmú, többgyermekes, szociális támogatásra szoruló falusi családok nem képesek. Az ilyen házak vagy üresen állnak, vagy a tanács megve- 
szi és szociális bérlakásként kiutalja, illetve a lehetôségektôl függôen tanácsi értékesítésû̉ lakásként eladja. Azaz a helyi tanács anyagi helyzete és az apparátus hozzáállása a döntố, amit általában megalázó bürokratikus procedúra is kísér.

A kedvezményes hosszúlejáratú kölcsönök és az elôirt feltételek változásait részletesen áttekintve itt is a szociálpolitikai támogatásnál bemutatott tendencia figyelhetố meg. A hetvenes években kiemelten preferálták a többszintes társasházakat és a családi házaknál is különbséget tettek a településtípus szerint. A megkülönböztetések és a már kabaréba illố aprólékos szabályozások (amelyeket a bemutatott 1981-1982-es hitelpolitika húen érzékeltet) fokozatos eltüntével kialakult a lakásépítés területileg is egységesebb, elsôsorban az építố anyagi helyzetén alapuló hitelezési rendszere. A kamatok átvállalásának jelenlegi szabályozása figyelembe veszi ugyan az életciklusokat, a fiatalok terheit a lakás vásárlása utáni elsố években az állam részben átvállalja, de most nem szociális szempontok alapján járnak ezek a kedvezmények, hanem mindenki igénybe veheti, jövedelmi, vagyoni helyzetétôl nagyrészt függetlenül.

\section{A lakásépitések településtípusonkénti és regionális sajátosságai}

Az elốzô fejezetekben a differenciált szociálpolitikai támogatások és hitelfeltételek áttekintésekor csak röviden tértünk ki néhány általuk okozott területi és településtípuskénti sajátosságra. A társasházak preferálása, a családi házak háttérbe szorítása milyen fontosabb területi hatásokat váltott ki, miként befolyásolta a lakásépítések alakulását? - ezzel a kérdéssel foglalkozik a tanulmány következố része.

Az 1971 és 1989 közötti lakásépítések fajlagos (ezer lakosra jutó) mutatóit három idôszakaszban: 1971 és 1977, 1978 és 1982, valamint 1983 és 1989 között három csoportra bontva vizsgáljuk: Budapest, többi város és községek felosztásában (5. táblázat). ${ }^{12}$

5. TÁBLÁZAT

Az 1000 lakosra jutó épített lakások száma a pénzügyi források és épitési forma szerint (db)

\begin{tabular}{|c|c|c|c|c|c|c|c|c|}
\hline & & \multirow[b]{2}{*}{$\begin{array}{l}\text { Lakás- } \\
\text { építés } \\
\text { összesen }\end{array}$} & \multirow[b]{2}{*}{$\begin{array}{l}\text { Állami } \\
\text { lakás- } \\
\text { építés }\end{array}$} & \multicolumn{2}{|c|}{ ebbốl } & \multirow[b]{2}{*}{$\begin{array}{l}\text { Magán- } \\
\text { lakás- } \\
\text { épités }\end{array}$} & \multicolumn{2}{|c|}{ ebbốl } \\
\hline & & & & $\begin{array}{c}\text { tanácsi } \\
\text { bérlakás }\end{array}$ & $\begin{array}{l}\text { tanácsí } \\
\text { értéke- } \\
\text { sítésú }\end{array}$ & & $\begin{array}{l}\text { több- } \\
\text { szintes } \\
\text { társasház }\end{array}$ & $\begin{array}{l}\text { családi } \\
\text { ház }\end{array}$ \\
\hline \multirow{3}{*}{ Budapest } & $1971-76$ & 46,4 & 29,1 & - & - & 17,3 & - & - \\
\hline & $1977-82$ & 49,8 & 32,0 & 18,4 & 12,0 & 17,9 & 12,2 & 4,2 \\
\hline & $1983-89$ & 37,5 & 12,8 & 7,7 & 2,5 & 24,7 & 17,7 & 5,3 \\
\hline \multirow{3}{*}{$\begin{array}{l}\text { Többi } \\
\text { város }\end{array}$} & $1971-76$ & 68,4 & 33,7 & - & - & 34,7 & - & - \\
\hline & $1977-82$ & 61,6 & 25,5 & 14,9 & 8,2 & 36,1 & 22,9 & 12,9 \\
\hline & $1983-89$ & 50,7 & 8,0 & 5,6 & 1,2 & 42,7 & 22,0 & 19,8 \\
\hline \multirow{3}{*}{ Községek } & $1971-76$ & 41,6 & 2,4 & - & - & 39,5 & - & - \\
\hline & $1977-82$ & 36,8 & 2,5 & 1,2 & 0,2 & 34,3 & 2,8 & 31,0 \\
\hline & $1983-89$ & 37,2 & 1,5 & 0,7 & 0,1 & 35,7 & 1,4 & 33,6 \\
\hline \multirow{3}{*}{ Ország } & $1971-76$ & 51,1 & 17,4 & 8,8 & - & 33,7 & - & - \\
\hline & $1977-82$ & 47,8 & 16,1 & 9,2 & 5,2 & 31,7 & 11,5 & 19,6 \\
\hline & $1983-89$ & 42,1 & 6,1 & 3,9 & 0,9 & 35,9 & 11,4 & 22,7 \\
\hline
\end{tabular}

Megjegyzés: 1980-ig az épített lakások adataiban szerepelnek az üdülók adatai is, 1983-tól a csoportos korszerú és családi ház együtt szerepel. 
A lakásépítések mennyiségi adatait elemezve látható, hogy a fốvárosi építkezések nagyjából az országos átlagnak felelnek meg, a többi város átlaga mindig fölötte, a községeké pedig alatta helyezkedik el. A fennálló különbségek ellenére az összes lakásépítést tekintve a három csoport közötti mennyiségi eltérések nem számottevốek. Jelentôs differenciákat okozott viszont a pénzügyi erôforrások aránytalan összetétele. Amíg Budapesten és a városokban közel hasonló nagyságban épültek állami erôforrásból lakások, addig a községekben a városi átlagnak csak a tizedrésze. Azaz a magyarországi lakosság felének (mintegy ötmillió embernek, akik közül szintén sok a kis jövedelmứ, gyerekes család, avagy egyéb okok miatt szociálisan rászoruló) reménye sem lehet állami erôforrásból épülő lakásra.

A tanácsi értékesitésũ lakások is erổteljes fổvárosi túlsúllyal épültek, amelyek vẻtelárának $40 \%$-át az állam állta és a maradék összegnek is csak $10 \%$-át kellett készpénzben kifizetni, a többi kedvezményes kamatozású hitel volt. Részben a negyvenes évek végén történt államosítások, részben az állami erôforrásokból épített lakások szociális szempontokat nélkülözô területi elosztása okozta azt, hogy míg a tanácsi bérlemények az összes lakásnak Budapesten $58 \%$-át, a többi városban $25 \%$-át, míg a községekben $1,2 \%$-át teszik ki, az ország tanácsi bérlakásainak $62 \%$-a a fỗvárosban találhatóo. ${ }^{13}$ Falvakban nincs értelme tanácsi bérlakásra benyújtani az igényeket, mivel sem újonnan épültre, sem régire nincs esély. Nyomtatványok helyett lottót kitöltve talán nagyobbak az esélyek...

A magánlakások vidéken nagyjából azonos ütemben épültek. A fổvárosban a magánépítkezések jelentôsen elmaradtak a többi településtốl, mintegy felét tették ki az országos átlagnak, még a többszintes társasházak építése sem érte el a többi város átlagos ütemét. A községekben épült lakások 80-90\%-a családi ház, a társasházak aránya itt elenyészô.

A fentiek alapján egyáltalán nem túlzás azt állítani, hogy a szociál- és hitelpolitika 1982-ig az ország felérôl nem vagy alig vett tudomást, a falvak lakosságát magára hagyták lakásgondjainak megoldásában. Ebben bizonyára néhány ideológiai megfontolás, a városi lakosság, a munkásosztály, az ipar támogatása is szerepet játszott, de a társadalmilag néma falusi tömegek csendes tû̃rését is számításba vehették. A lakosság anyagi forrásainak leterhelése a fôvárosban elenyészổ, a lakásokra szánt állami pénzeszközök nagyobb része Budapestre koncentrálódott. A többi városban a jelentôs számú magánerổs társasház és a családi házak miatt már valamivel nagyobb a lakosság anyagi áldozata, míg a községekben igen nagyarányú. A szociálpolitikai kedvezmények 1982 utáni változása is valószínúleg hozzájárult ahhoz, hogy a családiház-építések száma nốtt, miközben a lakásépítés összességében mindenütt visszaesett.

Az Országos Településhálózat-fejlesztési Koncepció(OTK) 1971-tốl fogalmazta meg a településfejlesztés követendỏ irányelveit. A településeket merev hierarchia szerint csoportosították, implicite sugallva egyes típusok magasabb- avagy alacsonyabbrendưségét. Az építkezéseket a hierarchia egyes lépcsổi szerint elemezve a város és község megkülönböztetéséhez képest jóval árnyaltabb képet kapunk (6. táblázat).

A településhálózati szerepkörök szerint kiszámolt adatok azt mutatják, hogy ez a hierarchia határozta meg döntổ módon az egyes településeken folyó lakásépítések sajátosságait is. Az építkezések nagysága mindegyik típusnál jelentôs, a fennálló különbségek alig számottevôek. A felsốbb szintektốl lefelé haladva viszont erổteljesen csökkennek az állami erōforrásból épített lakások és a telepszerú többszintes társasházak, míg ezzel ellentétesen nyilván nổnek a magánlakások és a családi házak építésének ezer lakosra jutó mutatói: A leghátrányosabb helyzetben 
6. TÁBLÁZAT

Az 1000 lakosra jutó épített lakások száma (db) és aránya (\%) a települések településhálózati szerepköre szerint 1971 és 1984 között

\begin{tabular}{|c|c|c|c|c|c|c|c|c|c|}
\hline & \multirow{2}{*}{\multicolumn{2}{|c|}{$\begin{array}{l}\text { Az } 1000 \text { lakosra } \\
\text { jutó épített lakások } \\
\text { száma }(\mathrm{db})\end{array}$}} & \multicolumn{7}{|c|}{ Az 1978 és 1984 között épített lakások megoszlása } \\
\hline & & & \multicolumn{4}{|c|}{ Pénzügyi forrás szerint } & \multicolumn{2}{|c|}{ Építési forma szerint } & \multirow{3}{*}{$\begin{array}{l}\text { Állami (OTP) } \\
\text { kölcsön } \\
\text { nélkül (\%) }\end{array}$} \\
\hline & \multirow{2}{*}{$1971-77$} & \multirow{2}{*}{$1978-84$} & \multicolumn{2}{|c|}{ Állami erốforrás } & \multicolumn{2}{|c|}{ Magán forrás } & \multirow{2}{*}{$\begin{array}{l}\text { Telepszerú } \\
\text { többszin- } \\
\text { tes (\%) }\end{array}$} & \multirow{2}{*}{$\begin{array}{l}\text { Egyedi } \\
\text { családi } \\
\text { ház (\%) }\end{array}$} & \\
\hline & & & (db) & $(\%)$ & $(\mathrm{db}$ & $(\%)$ & & & \\
\hline Országos központ & 45,8 & 54,2 & 31,0 & 57,2 & 23,2 & 42,8 & 79,5 & 9,0 & 0,6 \\
\hline Kiemelt felsớfokú & & & & & & & & & \\
\hline központ & 72,8 & 69,3 & 36,7 & 52,9 & 32,6 & 47,1 & 81,9 & 11,9 & 0,9 \\
\hline Felsófokú közp. & 79,6 & 71,9 & 24,9 & 34,6 & 47,0 & 65,4 & 76,8 & 18,3 & 1,4 \\
\hline Felsơfokú társközp. & 81,2 & 69,7 & 27,5 & 39,6 & 42,2 & 60,4 & 80,5 & 11,4 & 0,6 \\
\hline Középfokú közp. & 64,1 & 62,7 & 15,9 & 25,2 & 46,8 & 74,8 & 57,6 & 35,2 & 2,8 \\
\hline Középfokú társközp. & 58,4 & 57,6 & 8,6 & 15,0 & 49,0 & 85,0 & 37,5 & 55,5 & 4,5 \\
\hline Alsófokú közp. & 39,8 & 42,7 & 2,2 & 5,3 & 40,5 & 94,7 & 5,8 & 88,5 & 9,2 \\
\hline Budapesti aggl. & 60,7 & 72,1 & 5,3 & 7,4 & 66,8 & 92,6 & 25,6 & 69,2 & 8,4 \\
\hline Alapfokú települések & 30,5 & 28,5 & 1,2 & 4,2 & 27,3 & 95,8 & 4,6 & 92,9 & 8,4 \\
\hline Ország összesen & 50,5 & 52,7 & 15,4 & 29,3 & 37,3 & 70,7 & 50,4 & 42,4 & 4,0 \\
\hline
\end{tabular}

Megjegyzés: Az építési forma szerinti megoszlásnál az állami és magánlakás-építést együtt vettük. Az alsófokú központokat 1981-ig három részre osztották; kiemelt alsófokú, alsófokú és részleges alsófokú központokra. 1980-ig az adatok között az idényszerú használatra épített lakások is szerepelnek. A KSH csak 1984-ig közli az OTK-hierarchia szerinti adatokat.

lévổ alapfokú településeken is olyan mértékben épülttek magánerốs lakások, mint a felsôfokú központokban (sốt túlszárnyalták a fớvárost), csakhogy az elốbbiekben 93\%-ot tett ki a diszpreferált családi házak aránya és minden tizedik mindenféle állami támogatás nélkül épült. Minél több lakótelep épül valahol, lehetốleg nagy állami támogatással és bérlakásokból, annál fejlettebb a település és annál fontosabb települáshálózati funkciói vannak? Avagy fordítva, minél nagyobb egy város rangja, a lakossága annál több állami lakásra és pénzügyi kedvezményre számíthat?

Az építkezések jellemzỗi alapján a hierarchián belül három csoport különíthetổ el. Az országos központ (Budapest) és a felsổfokú központok (a megyeszékhelyek és még öt nagyobb város) egy csoportot alkotnak, alig van közöttük különbség az állami erốforrásból történô építkezéseket és a telepszerư többszintes lakások arányát tekintve. A elsôfokú központok között jelentôs eltérések csak a magánerổs építéseknél figyelhetốk meg. A középfokú központok és társközpontok al kotják a második csoportot (városok és nagyobb községek), ahol az országos átlaghoz közeli adatok és arányok regisztrálhatók. A harmadik csoportba az alsófokú központok és alapfokú települések tartoznak, talán ide sorolható még a budapesti agglomeráció is. Az elsố csoportba tartozó mintegy négymillió lakos tekinthetố a redisztribúció haszonélvezôjjének, mivel az országos központban és a felsôfokú központokban épültek az állami lakások, valamint a kedvezményes hitelekkel és szociálpolitikai támogatásokkal gyámolított többszintes társasházak. A második csoportba tartozó kétmillió lakos már jóval kevesebb támogatást kapott, míg a har- 
madik csoport négy és fél millió lakosa állami lakásról nem is álmodhatott, minimális segítséggel maga építette fel a hajlékául szolgáló családi házat.

A lakásépítéseket tervezési-gazdasági körzetenként vizsgálva az állapítható meg, hogy a lakások kis eltérésekkel területileg viszonylag egyenletesen épültek (7. táblázat). 1982-ig az állami lakásépitésnél mind a bérlakások, mind a tanácsi értékesítésũ lakások tekintetében a központi,

7. TÁBLÁZAT

Az 1000 lakosra jutó épített lakások száma pénzügyi forrás és építési forma szerint tervezési-gazdasági körzetenként $(\mathrm{db})$

\begin{tabular}{|c|c|c|c|c|c|c|c|c|c|}
\hline \multirow{2}{*}{\multicolumn{2}{|c|}{$\begin{array}{c}\text { Tervezési-gazdasági } \\
\text { körzetek }\end{array}$}} & \multirow{2}{*}{$\begin{array}{l}\text { Lakás- } \\
\text { építés } \\
\text { összesen }\end{array}$} & \multirow{2}{*}{$\begin{array}{l}\text { Állami } \\
\text { erốfor- } \\
\text { rásból }\end{array}$} & \multicolumn{2}{|c|}{ Ebbốl } & \multirow{2}{*}{$\begin{array}{l}\text { Magán- } \\
\text { lakás- } \\
\text { épités }\end{array}$} & \multicolumn{3}{|c|}{ Ebbôl } \\
\hline & & & & tanácsi & tanácsi & & telepszerú & családi & Állami \\
\hline \multirow{3}{*}{ Központi } & $1971-76$ & 46,9 & 22,5 & - & - & 24,4 & - & - & 3,5 \\
\hline & $1977-82$ & 48,9 & 23,6 & 13,5 & 8,6 & 25,3 & 8,7 & 13,7 & 1,1 \\
\hline & $1983-89$ & 38,9 & 9,1 & 5,5 & 1,7 & 29,8 & 12,4 & 13,7 & 0,6 \\
\hline \multirow{3}{*}{$\begin{array}{l}\text { Észak- } \\
\text { dunántúli }\end{array}$} & $1971-76$ & 54,1 & 21,4 & - & - & 32,7 & - & - & 4,2 \\
\hline & $1977-82$ & 45,7 & 13,9 & 9,0 & 4,5 & 31,8 & 12,2 & 19,4 & 1,1 \\
\hline & $1983-89$ & 42,0 & 5,5 & 3,7 & 0,5 & 36,5 & 10,2 & 23,9 & 0,6 \\
\hline \multirow{3}{*}{$\begin{array}{l}\text { Dél- } \\
\text { dunántúli }\end{array}$} & $1971-76$ & 43,9 & 12,6 & - & - & 31,3 & - & - & 5,4 \\
\hline & $1977-82$ & 42,1 & 15,3 & 6,6 & 3,3 & 26,8 & 13,4 & 17,6 & 1,0 \\
\hline & $1983-89$ & 40,7 & 5,2 & 3,4 & 0,4 & 35,5 & 12,8 & 20,4 & 0,6 \\
\hline \multirow{3}{*}{ Észak-alföldi } & $1971-76$ & 53,2 & 13,3 & - & - & 39,9 & - & - & 5,8 \\
\hline & $1977-82$ & 47,9 & 11,0 & 6,4 & 3,5 & 36,9 & 7,5 & 28,3 & 1,7 \\
\hline & $1983-89$ & 50,2 & 4,9 & 3,3 & 0,8 & 45,3 & 9,6 & 34,6 & 0,7 \\
\hline \multirow{3}{*}{ Dél-alföldi } & $1971-76$ & 52,0 & 11,0 & - & - & 41,0 & - & - & 6,4 \\
\hline & $1977-82$ & 57,5 & 11,8 & 6,2 & 4,2 & 45,7 & 12,6 & 24,1 & 1,3 \\
\hline & $1983-89$ & 44,4 & 4,0 & 2,6 & 0,7 & 40,4 & 12,1 & 36,2 & 1,1 \\
\hline \multirow{3}{*}{$\begin{array}{l}\text { Észak-ma- } \\
\text { gyarországi }\end{array}$} & $1971-76$ & 43,7 & 17,4 & - & - & 29,8 & - & - & 3,0 \\
\hline & $1977-82$ & 49,2 & 14,1 & 9,3 & 3,6 & 35,1 & 7,1 & 19,7 & 1,0 \\
\hline & $1983-89$ & 38,4 & 4,8 & 3,3 & 0,8 & 33,6 & 7,1 & 24,9 & 0,5 \\
\hline \multirow{3}{*}{ Ország } & $1971-76$ & 49,5 & 17,4 & - & - & 32,1 & - & - & 4,5 \\
\hline & $1977-82$ & 46,5 & 16,1 & 9,2 & 5,2 & 30,5 & 10,1 & 19,5 & 1,3 \\
\hline & $1983-89$ & 41,9 & 6,1 & 3,9 & 0,9 & 35,8 & 10,9 & 22,5 & 0,7 \\
\hline
\end{tabular}

Megjegyzés: az idényszerũ használatra épített lakásokat nem vettuik figyelembe, 1983-tól a családi házakhoz soroltuk a csoportos korszerũ lakóházakat is.

az észak-dunántúli és az észak-magyarországi körzetek, azaz az iparosodottabb térségek élveztek elônyöket. Az állami építkezések területi differenciáit kiegyenlítették a magánerôs épittkezések, ahol a két alföldi körzet kimagasodik, jóval túlszárnyalva mindig a többi körzet átlagát. A telepszerú többszintes magánerốs társasházak építésére kisebb regionális eltérések jellemzốk; az észak-magyarországi és az észak-alföldi körzetekben maradtak el mindig a többi körzettốl. Jóval nagyobb különbségek mutatkoznak a családiház-építésnél; az Alföldön ez az építési forma mindvégig kiemelkedổ és meghatározó. 
Vajon az állami lakásépítés területi egyenlốtlenségeit, a kiemelt szociálpolitikai támogatást és a magasabb társasházi hiteleket indokolja, hogy az építési költségek, a lakások árai területileg igen eltérổek? Az állami építôipari vállalatok (akik a társasházak döntớ hányadát építették) egy négyzetméter lakásterületre jutó nettó épitési költségei 1976 és 1989 között a megyéket és a régiókat tekintve alig térnek el egymástól. Az országos átlagot a fôváros mindig meghaladja 6-8\%-kal, az átlag alatt pedig a megyék váltakozva szerepelnek, a ,legolcsóbb” általában 15-20\%-kal. Azaz a társasházak építési költségeinek regionális eltérései nem indokolják az állami lakásépítés területi anomáliáit. A családi házak becsült építési költségei mindegyik régióban meghaladják a társasházi lakásokét (igaz, hogy alapterületük is jóval nagyobb), így az önköltségekkel nem indokolhatók az utóbbiak számára kedvezổbb szociálpolitikai támogatások és a nagyobb kedvezményes hitelek. ${ }^{14}$ A családi házak építési költségei régiónként is nagy határok között ingadoznak, a fôvárosban 25-30\%-kal magasabbak az országos átlagnál. Jelentôs differenciáló tényezó a telekár, illetve a telekhasználatbavételi díj, amely a fốvárosban és a nagyobb városokban az építkezés költségeinek negyedét-ötödét is kiteheti.

A lakásépítések településtípusok közötti különbségei alapján egyértelmúen kitünik, hogy a vizsgált idốszak lakáspolitikája - miként az a hosszabb távú lakásépítési programokban meg is lett hirdetve - szinte kizárólag a nagyobb városok és néhány ipari város erôltetett fejlesztését támogatta. A regionális különbségek is fốleg abból adódtak, hogy egy térségben a nagyobb városok mennyire hatékony lobbyzásra voltak képesek. A lakás-, szociál- és hitelpolitika igazi kárvallottjának az ország lakosságának közel fele tekinthetô, azok, akik kisebb településeken élnek. A régiók közül az Alföldet érték hátrányok, ahol kevés állami lakás és sok magánerôs családi ház épült. Úgy tửnik, hogy a területfejlesztés, és ezen belül a lakáspolitika különbözố indíttatású alapelvei és magyarázatai a valóságnak ugyanazon arcát kendôzik el; a szükös erõforrások mindenáron történô megszerzéséért folyik a küzdelem. ${ }^{15}$

\section{Töprengések a lakáskérdés területiségéról}

A lakásprobléma rendkívül összetett, nemcsak gazdasági, hanem társadalmi és politikai kérdés is. Dolgozatunkban elsổsorban az egyenlôtlen és antiszociális redisztribúciót bíráltuk, amely a lakosság jelentốs részéról elfeledkezett (ráadásul az alacsonyabb jövedelmú és képzetlen falusi népességrốl, akik közül igen sok a szociális szempontok szerinti rászoruló), és olyan kényszerhelyzet elé állította ốket, amelybôl csak önsanyargatással képesek úgy-ahogy kilábalni. Mi több, ez a redisztribúció a ,,szociálpolitika" fedônevet viselte. Az utóbbi évekre a magánerốs építkezések támogatása egységesebb lett, a redisztributív mechanizmusok lényegesen átalakultak, de ma még nem látható az, hogy a piaci viszonyok megerốsödésével ezek a mechanizmusok elegendốek lesznek-e a kiélezốdố társadalmi egyenlôtlenségek kezelésére. Viszont az is igaz, hogy a szociális feszültségeket fốleg az állami lakások szociális szempontú bérbeadásával, és nem a magánépítkezésekkel lehet feloldani.

A probléma összetettsége, az átalakuló magyar gazdaság és társadalom ma még csak felsejlő sorskérdései a lakásépítések regionális kérdéseivel érintôlegesen foglalkozó kutatónál nem teszik lehetôvé a vizsgálat megnyugtató lezárását: egy sereg újabb kérdés vetớdik fel az alapok újragondolásának igényével. Csak néhány a feltoluló gondolatok közül. 
Megszüntethetổ lesz-e a lakáshiány piaci viszonyok között? Ez attól függ, hogy a kereslet és kínálat között úgy-ahogy kialakuló egyensúly peremfeltételeit figyelembe vesszük-e. A lakás azért is különleges áru, mivel egyúttal ingatlanjellegû́ megtakaritás és státuszszimbólum is, nemcsak a munka utáni pihenés és családi élet színtere. Ráadásul a vizsgált években a magántulajdon korlátozása és a biztosítások kezdetlegessége miatt a lakások vagyonmegörzó jellege roppantul felerôsödött és növelte a lakások iránti keresletet. Részben a fentiekkel összefüggésben és a lakásszükséglet majdnem-telíthetetlen jellege miatt már-már széles körben nyilvánvalóvá vált az, hogy a hiány kínálati oldalról nem szüntethetó meg. Nemcsak nálunk, hiszen még a jóval gazdagabb országok polgárainak is vannak elképzeléseik egy , jobb" lakásról. ${ }^{16} \mathrm{~A}$ piaci viszonyok térnyerésével valószínüleg beszúkkül a kereslet, és elérhetố a lakáshiány látszólagos enyhülése, viszont óriási szociális és társadalmi feszültséget okoznak a hajléktalanok és hátrányos helyzetũek problémái.

A szociálpolitikai támogatások és a kedvezményes kölcsönök odaítélésénél nem vették figyelembe a rászorultságot. A lakáspolitika egészen az utóbbi évekig a nagyobb jövedelmũ és kvalifikált rétegeknek kedvezett, hozzájárult a társadalmi hátrányok felhalmozódásához, így semmiképpen sem volt szociálpolitikai vonatkozása. Ha a város - falu különbséget vizsgáljuk, akkor az elmúlt rendszer szociálpolitikája kiélezte az egyenlốtlenségeket, nem szolgálta az életkörülmények területi kiegyenlítődését. Igaz ez, avagy városban nehezebb az élet és több a rászoruló, mint falun, ezért jogos volt a városi lakásépítések kiemelt támogatása?

Egy a nyolcvanas évek elején lezajlott felmérés a súlyosan hátrányos helyzetưek, a depriváltak településtípusonkénti eloszlásánál a következôket állapította meg: a budapestieknek 4\%-a, a vidéki városokban lakóknak 7\%-a, a falvakban lakóknak 19\%-a deprivált. A deprivációval veszélyeztetettek aránya az elốbbi sorendben: $12 \%, 13 \%$ és $25 \%,{ }^{17}$ azaz a falun élốknek majdnem fele szegénynek nevezhetổ, míg a vidéki városokban minden ötödik, a fốvárosban minden hatodik lakos. Hosszabb idôszakot tekintve a házasságukat albérletben vagy a szülốk lakásában kezdô fiatal házasok aránya Budapesten $42 \%$, a községekben $65 \%$, tehát a lakások iránti igény is jóval erôsebb falun. ${ }^{18} \mathrm{~A}$ jövedelmekre közelítố becslést nyújt az 1988-dik évi személyi jövedelemadó, amely egy lakosra számolva a fốvárosban 12.600 forint, a vidéki városokban 6.800 forint, a községekben 3.900 forint. ${ }^{19}$ A fenti vizsgálatok eredményei összecsengenek: a falun élók (pontosabban igen nagy arányuk, eltekintve az ott is megtalálható vagyonos rétegtốl) a leginkább rászorultak, a legnehezebben tudják megoldani lakásgondjaikat, ennek ellenére az állami szociálpolitika a szép szavakon kívül szinte semmilyen segítséget nem adott. A házépítések támogatása azért is alapvetố lett volna, mivel a falusi lakosság életkörülményeinek differenciálódásában a lakásviszonyok játsszák a fôszzerepet. ${ }^{20}$

Érdekes összefüggéseket mutat a lakásépitésbe befektetett anyagi eszközök számbavétele, amelyek a népgazdasági beruházásoknak kb. 18-20\%-át tették ki. 1971 és 1985 között az állami lakásépítésre (fốleg célcsoportos lakásépítésre) folyó áron számolva 178.6 milliárd forintot, a személyi tulajdonú lakásépítés állami támogatására 68.4 milliárd forintot fordítottak, miközben a magánerôs építkezések lakossági terhei becsült adatok alapján kb. 450 milliárd forintra rúgtak. ${ }^{21}$ A magánlakás-építés állami támogatásából a szociálpolitikai kedvezmények 30.3 milliárd forintot (mintegy kétharmada megelôlegezett támogatás), az új lakáshoz nyújtott kamatkedvezmények 19.6 milliárd forintot tettek ki. Ha 1970-es árakon hasonlítjuk össze az infláció és az idốbeli hullámzás miatt ezeket a ráfordításokat, akkor a lakossági terhek majdnem háromszoro- 
sát teszik ki az állami kiadásoknak (lakásépítést és támogatást együttesen véve). A lakosság tehervállalása pedig településenként nagyon eltérô, kisvárosokban és községekben a legnagyobb. Mindehhez hozzá sem kell adni az állami lakások korszerûsítésére és fenntartására fordított összegeket ahhoz, hogy az állami költségvetés nagyváros-centrikussága egyértelmúen kiderüljön. (Avagy a döntéshozók és -elốkészítốk zöme Budapesten lakva érvényesítette a ,,minden szentnek maga felé hajlik a szociális keze" alapelvet?) 1990-ben a 100 lakásra jutó lakosok száma Budapesten 255 fố, a vidéki városokban 275 fổ, a községekben 273 fổ volt. A területileg viszonylag egyenletes lakáshiány sem támasztja aláa , ,szociális" célú pénzösszegek nagyvárosi felhasználását.

Az építkezéseknél a lakossági tehervállalások területi egyenlốtlenségeit jól érzékelteti a lakossági hitelek és betétek nagysága, valamint az aránya (ami a lakosság , ,eladósodására” utal). Az egy lakosra jutó betét 1988 végén Budapesten 51 ezer, vidéken 24 ezer forint volt (ez utóbbi megoszlása: városokban 28 ezer, míg falvakban 20 ezer forint). Az egy lakosra jutó hitelállomány a fốvárosban 24 ezer, vidéken 30 ezer forint. A hitelek és betétek aránya jelentớs makroregionális eltéréseket takar: az Alföldön 133\%, Észak-Magyarországon 113\%, a Dunántúlon $110 \%$, a budapesti agglomerációban $65 \%$. Kisebb térségeket, településeket nézve az ipar- és városhiányos agrártérségekben a legnagyobb az eladósodás (mértéke 3-4-szeres is lehet). ${ }^{22}$ A vidéki lakosság eladósodásához hozzájárult az is, hogy a tanácsi pénzeszközök redisztribúciójakor is háttérbe szorultak (ez kitũnt az állami lakásépítés vizsgálatakor is), a lakossági infrastruktúra fejlesztését döntô módon saját erôbốl, hiteleket felvéve tudták csak megoldani. ${ }^{23}$

Milyen ideológiai elképzelések, vagy azokkal leplezett érdekek befolyásolták az állami szubvenciók egyenlốtlenségeit? A tulajdonformáknál sokáig alaptételként elfogadott, ,,felsôbbrendũséget" mutató rangsor: állami, szövetkezeti és magántulajdon. Ez a lakásoknál mindkét 15 éves lakásépítési programban a következốképpen jelent meg: állami bérlakás, többszintes társasházi magánlakás és családi ház. Amíg az állami bérlakások építésének költségeit teljesen az állami költségvetés fedezte, a többszintes társasházi lakásoknál jóval kisebb, de azért még számottevổ az állami szubvenció (fiktív telekárak, jelentôs állami támogatás), addig a családi házakat csak megtứrték, alig támogatták (az építőanyagok árát dotálták, illetve a már részletezett kedvezményeket adták). Ez a hierarchia a településeknél is megmutatkozott: fốváros (ahol a vizsgált években épült lakások közel fele állami bérlakás, a többinek is nagy része többszintes társasház), nagyobb vidéki városok (ahol jelentớs számban épültek a lakótelepeken és a városközpontok rekonstrukciójakor többszintes lakóházak), a többi város és község (itt szinte kizárólag családi házak épültek). Ezáltal a lakásépítés állami ,támogatása” a települések közötti egyenlốtlenségeket konzerválta, az életkörülmények területi különbségeit nem mérsékelte, sốt inkább növelte. A tanácsi bérlakás kiutalásakor a pillanatnyi jogosultságot vették figyelembe, a bérlemény szinte kvázi-örökölhetớ, és a szociålis rászorultság megszúnése utån is marad az alacsony lakbér, miáltal a nagyvárosokban (fóleg a fơvárosban) a magas jövedelmúek is kaptak állami támogatást, elvonva a pénzt és a lakást az igazán nehéz helyzetben lévôktốl. Hasonlóan a vagyonosoknak kedvezett a hosszúlejáratú kedvezményes hitelek egy összegben történổ viszszafizetése. 1989-ben már a tartozás 45\%-át engedték el, vagyis az állami költségvetés odaajándékozta ezt az összeget. A kamatadó hírére 1989 végén a tehetôsebbek villámgyorsan tehermentesítették lakásukat (jelenleg $25 \%$-ot engednek el). 
Mennyiben befolyásolta a lakásépítések állami támogatása a magyarországi urbanizációt, városaink képét vagy a migrációt? Lehet, hogy piaci viszonyok között is hasonlóan alakulnak az egyes településeken a lakásépítések? Véleményem szerint aligha, de erre a kérdésre nálam avatottabbak tudnak hitelt érdemlôen válaszolni. Elég csak a vagyonmegốrzés hazai sajátosságaira, az ingatlanszerzés adminisztratív korlátozására, az üdülôk és hétvégi házak fokozott építésére, avagy a földvédelmi törvényekre és a külterületi építési tilalmakra gondolunk. Még egy formális cím iránti, a városi státus elnyeréséért kifejtett erôfeszítések is részben érthetổek fenti adatok ismeretében. A városok nemcsak jóval nagyobb tanácsi fejlesztési alapokkal rendelkeztek, hanem a lakossági építkezésekhez a támogatások, kedvezmények is sokkal nagyobbak voltak, mint a községekben. Így érthetổ az is, hogy a városkörnyéki falvak építkezô lakosságának is elổnyös volt (legalábbis ebból a szempontból), ha a város a közigazgatási határát kiterjesztve településüket ,,bekebelezte”. Egy másik apróság - mint már említettük -, az ajánlott típustervek alapján épülổ családi házra 10\%-kal nagyobb hitelt lehetett felvenni, ami vonzóbbá tette a , kockaházak diszkrét báját". Nem is szólva a házadóról, amely egy- és kétlakásos épületekben csak a 100 négyzetméternél nagyobb alapterületũ lakásokra volt kivetve (részben ezért voltak felkapottak a tízszer-tíz méteres típustervek), és a hitelek összegéról, amely eleve csak a kisebb családi házak építését tette lehetỗvé. Természetesen a hagyományos családiház-építéseket falun nem csupán a kényszer diktálta, mivel máshogy nehezen lehetett megoldani a lakásgondokat, hanem a házkörüli gazdálkodás tradíciói (fốleg az agrártérségekben), az élelmiszerönellátás hagyománya, a második gazdaság fellendülése stb. is ösztönözték.

A lakásépítés, miként általában az infrastruktúra fejlesztése, csak amolyan megtứrt, a nemzeti jövedelmet fogyasztó, nem-termelônek minősített tevékenység volt, amelyet a paternalista állam bizonyos társadalmi és politikai nyomás hatására kényszerúen elvégzett. Ez a szemlélet a vizsgált idốszakban végig jelen volt, így igazán nem csodálkozhatunk azon, hogy mára már nem maradt nyertese a korábbi évek lakáspolitikájának (miként az erôltetett iparfejlesztésnek sem). Az ügyeskedốket és a bérlakásokban éló gazdagabb réteget kivéve ugyanúgy kiszolgáltatott áldozatnak tekinthetô a lerobbant bérlakásban tengổdô nagyvárosi lakos, mint a házépítés terheit nyögổ falusi ember. Viszont az is igaz, hogy a korábbi években az olcsó tanácsi bérlakásokban élốknek nagyobb lehetôségük volt különjövedelmek szerzésére (szobák bérbeadására), jóval több pénzük maradt a mindennapi fogyasztásra (vagy üdülốk építésére), mint a kölcsönöket törlesztổ, és házának fenntartását, felújitását is fizetổ egyénnek.

Úgy tửnik, hogy a nagyvárosokban levô magánlakások tulajdonosai járnak kevésbé rosszul a piaci viszonyok térnyerésével, mivel lakásuk forgalmi értéke már napjainkban is többszöröse lehet, mint a hasonló költséggel megépült falusi családi házaké. Ráadásul ezen házak többsége nincs közmứvesítve, a kezdetleges utak miatt a városi szolgáltatások nehezen érhetốk el stb., így a lakáspiacon a falusi házak folyamatosan alulértékelổdnek. Félổ, hogy az állami bérlakások privatizáciojakor csak a városi önkormányzatokhoz folyik be a pénz, a falvak viszont, ahol elenyészố az állami ingatlanok aránya, elesnek ezektôl az összegektốl, holott korábban a forrásokat tốlük is elvonták a bérlakás-építésekre. 


\section{Összegzés}

A vizsgált idốszakban a családi ház építõje sajátos piaci viszonyok közé került egy olyan redisztributív modellben, amelyben a bérek nem tartalmazták a munkaerô újratermelésének lakásköltségeit. Az állam ezeket az összegeket elvonta, és a szociális szempontoknak fittyet hányva, részérdekek alapján szétosztotta. Az újraelosztás során a vidéki kisvárosok, a falvak állami bérlakáshoz alig jutottak, családi házat építớ lakóik pedig teljesen háttérbe szorultak, alsóbbrendú állampolgárokká degradálódtak. Ez volt az egyik eszköze (avagy következménye?) a magyarországi indirekt falurombolásnak; csak a nagyobb városokat támogatták és magukra hagyták a többi település lakóit. Nemcsak a pénzügyi és egyéb szociális kedvezmény volt minimális, hanem az építôanyagok is szinte kivétel nélkül krónikus hiánycikkek voltak, a házépítések építốanyagiparának (pl. a tégla- és cserépipar) is csak a hetvenes évek vége felé hagyták, hogy fejlesztésekbe kezdjen, modernizálja és növelje kapacitásait.

Dolgozatunkban nem a családiház-építés mellett és a többszintes társasházak ellen próbáltunk érvelni, hisz mint építési formáknak mindegyiknek van elổnye és hátránya, hanem az antiszociális lakáspolitika néhány területi anomáliáját mutattuk be. Egy lakás hosszú idổe szól, és a lakók lehetôségeit, életminôségét nagyban meghatározza, ezért az elmúlt lakáspolitikának még hosszú évtizedekig élvezhetjük áldatlan kihatásait.

Van valamilyen pozitívuma a házépítés-ellenességnek? Egyet tudok csak kiemelni:- paradox módon a családi házat építố falusi emberek magukra hagyva, mély vízbe dobva az építkezés során és a , majdnem-piaci pénzcsináló” második gazdaságban is ,,kényszer-vállalkozókká” váltak. Nem az állam (és bürokráciája) mindenható kegyeiért tülekedtek, hanem saját kezdeményezố-képességüket felfedezve rádöbbentek, hogy önmagukért önmaguk tehetik a legtöbbet. Ez pedig egy autonómiára épüló, civil helyi társadalom jövendóbeli esélyeit növeli.

\section{Jegyzetek}

1 A dolgozat Lengyel Imre ,,A lakosság eladósodásának egyes regionális tényezơi” címú, a „,Megújítási pályák és lehetôségek a településekben, térségekben" OTKA-pályázat számára készített kézirat felhasználásával készuilt. A teljesség igénye nélkül említem azon szerzóket, akiknek a lakásprobléma gazdasági és szociális kérdéseivel kapcsolatos múvei a leginkább hatottak rám: Bokros Lajos, Dániel Zsuzsa, Farkas E. János, Liska Tibor, Mihályi Péter, Petsching Mária Zita, Szelényi Iván, Tosics Iván, Vajda Ágnes.

${ }^{2}$ Lásd. Petsching M. Z. (1986) A lakásárak emelkedésének okairól, Közgazdasági Szemle és Bokros L. (1988) Az áru és pénzviszonyok fejlesztésének feltételei a lakásgazdálkodásban, Közgazdasági Szemle 6.

3 Az adatokat az OTP Békés megyei Igazgatósága munkatársainak segítségével gyưjtöttem össze a ,,Lakásépítési-, -hitelezési és ingatlanforgalmazási tevékenységról" címú éves jelentésból. Segítơkészségüket ezúton is köszönöm.

4 Az OTP csak , megbízottként” végezte el a szociálpolitikai támogatásokkal kapcsolatos teendóket, mivel a minisz" tertanácsi rendeletek, valamint egyéb fóhatóságok (PM, ÉVM stb.) végrehajtási utasításai minden feltételt és szabályt részletekbe menóen elóírtak, amibe az OTP-nek nem volt beleszólása.

s. Lásd Vajda Á. (1986) Nagyvárosi és falusi lakásformák Statiszrikai Szemle, 8-9.

- Egy idómérleg-felvétel elemzésénél lásd: Farkas E.J., Vajda Á. (1988) Magánerố a lakásépítésben. Tervgazdasági Fórum, 4.

7 Pl. 1981-ben két gyerek vállalása esetén többszintes panelházban egy kétszobás lakás vételárának kb. 12-15\%-át fedezte a szociálpolitikai támogatás.

- Szelényi Iván a támogatás antiszociál is voltára közvetlenül a bevezetés után, 1972-ben felhívta a figyelmet kandidátusi értekezésében. Nyomtatásban megjelent: Szelényi I. (1989) Városi társadalmi egyenlótlenségek, Akadémiai Kiadó (A 96. oldalon fejti ki ezt a véleményét). 
- 1990 februárjától az új házasok az elsố lakás vásárlásakor 150 ezer forint vissza nem tếrítendố állami támogatást kapnak.

10 A hitelek összegét, kamatlábát, törlesztési idejét stb. szintén mindenre kiterjedően elôírták a fóhatóságok, az OTP csak végrehajtója volt ennek a hitelpolitikának.

it Lásd. Szelényi i.m.

12 A KSH 1977-től közli ,,Lakásépítés és megszûnés” (1983-tól ,„Lakásstatisztikai Évkönyv”) címmel a pénzủgyi források szerinti részletes adatokat, ezért a táblázatokban az 1971-1976, valamint az 1977-1982 közötti idổszakokat és az 1982-es lakásreformot kỏvetổ periódust különítettük el (az utóbbi 7 évet ölel fel, míg az elổzôek 6-ot). Tanácsi értékesítésú lakások csak 1985-ig fordultak eló.

13 Az ingatlankezeléssel foglalkozó tanácsi vállalatok, költségvetési üzemek 1988-adik évi adatai alapján, amelyben nem szerepelnek az egyéb szervek kezelésében lévổ bérlakások. KSH Statisztikai Évkönyv, 1988.

14 Az OTP nem igényelt tételes költségvetést családiház-építésnél, ezért itt csak közelítô, 1983-tól megfigyelt adatokról van szó. Egy családi ház felépítésének költsége nagy részt a telek árától és az építtetổ anyagi helyzetétól (egy bizonyos ősszegtốl kezdổően a mérettốl, felszereltségtôl stb.) függ.

15 A tanácsi gazdaságról (amelyik az állami lakásépítés zömét finanszírozta) részletesebben lásd. Vági G. (1982) Versengés a fejlesztési forrásokért, Közgazdasági és Jogi Könyvkiadó, valamint Lengyel I. (1989) Alföldi remények és , tanácstalanságok”. Közgazdasági Szemle, 6 .

16 A hiány , öngerjesztổ hatásának" területiségére kiváló tanpéldát szolgáltat a lakásépítés korábbi gyakorlata. A lakáshiányról lásd. Kornai J. (1980) A hiány, Közgazdasági és Jogi Könyvkiadó (518-527. oldal).

17 Lásd. Bokor Á. (1987) Szegénység a mai Magyarországon, Magvetó Kiadó.

18 Lásd. Vajda Á. i.m. Természetesen általában kedvezôbb a családi ház több generáció együttélésére, mint a kis alapterületũ társasházi lakás. A községekben az ismertetett arány hosszabb idôszakban nagyjából állandó, míg Budapesten emelkedổ tendenciájú.

19 Lásd. Nemes Nagy J. (1990) Hol terem a jó adófizetô? Gazdasági Fórum, 1.

20 Lásd. Enyedi Gy. (1990) Falvaink sorsa, Magvetố Kiadó.

21 Lásd. Jelentés a VI. ötéves tervidôszzaki lakásépítési, hitelesítési és ingatlan-forgalmazási tevékenységrôl. OTP 1986, valamint Farkas E. J. - Vajda Á. (1988) A lakásépítés második gazdasága, Arat a magyar, A Szociálpolitikai Értesító és Fejlödés-Tanulmányok Sorozat különszáma. MTA Szociológiai Kutató Intézet.

22 Errốl a témáról részletesebben lásd. Lengyel I. - Szekeres I. (1990) A lakosság eladósodásának néhány összefüggése Békés megyében, Békési Élet, 1. és ugyanezen szerzốktốl (1990). A lakossági betétek és hitelek alakulásának regionális sajátosságai 1970 és 1988 között, Bankszemle, 5.

${ }^{23}$ Lásd. Lengyel I. (1987) Hasonlóságok és eltérések az alföldi megyék VII. ötéves treveiben, Területı Statisztika, $1-3$.

\section{CHRONICLE OF (ANTI)SOCIAL HOUSING-CONSTRUCTION SUBSIDIES}

\section{IMRE LENGYEL}

In my study, I analyze the most important characteristics of housing construction in Hungary between 1970 and 1989 by regional and settlement types. In my investigations, I put special emphasis on two fields of housing policy: the changes of the amount of social subsidies given to private housing construction, and the conditions of getting construction loans under favourable terms.

During the period examined, housing constructions can be grouped into three types by their financial resources:

1. Construction of state-owned flats. Their construction costs were fully covered from the state (council) budget. The rents of these flats were low, and did not even cover the maintenance costs (in the capital city, these flats could be re-rented to sub-tenants for ten-times more than the official rent). 
2. Construction of private flats which were sold to individuals. In this case, the council had the right to select the purchaser on the basis of ,,socio-political" principles. * Their construction costs were covered up to $40 \%$ from the state budget. The buyer had to pay $10 \%$ of the purchase price in cash, and could get state loans under favourable terms to cover the rest of price.

3. Construction of owner-occupied private flats/houses. When buying or constructing these flats/houses, the buyer had to pay $30-50 \%$ of the construction costs in cash. For the remaining amount, either state loan under favourable terms could be drawn, or - depending on the number of children - non-repayable social subsidy could be received.

State housing and private flats sold to the individuals by the local councils were primarily built with the purpose of solving the housing problems of socially needy people (we have to note, that until the end of the $1980 \mathrm{~s}$, one family could only buy or rent from the state one flat/house only, so there could not be more than one flat/house in the property of one family). The investigations have, however, proved, that the first two types of flats were almost exclusively built in Budapest and the bigger towns, while their construction was very rare in smaller towns and villages, where close to $50 \%$ of Hungary's population lives. At the end of 1989, state housing in Budapest gave $58 \%$ of all flats, while this proportion was $25 \%$ in other towns and only $1.2 \%$ in the villages. These data, as opposed to the findings of another investigation proving that $19 \%$ of the population in the villages, $7 \%$ in the towns and only $3 \%$ in Budapest was deprivated, prove that housing policy did not meet socio-political requirements.

Until the end of the 1970 s, private housing construction was only tolerated by the official housing policy, because it supported state housing construction - in harmony with the prevailing ideology and in favour of state ownership. At around 1980 it became clear, that the state budget could not cover the costs of housing construction projects. As a result, the government started to promote and financially support private housing construction as well. By 1989, state housing construction practically ceased to exist, while in the 1970s this type gave one-third or even half of all flats constructed.

In the cases of owner-occupied, or private flats, two different categories can be differentiated by the amount/type of state subsidies. One of them is the group of privately-owned flats in multistory blocks of flats and the other is family houses. They could either be given state subsidy on the basis of the number of children, or long-term loans under favourable conditions. Official housing policy judged the above two categories differently. Until 1983, non-repayable state subsidy drawable according to the number of children was only due to those who purchased privately-owned flats in blocks of flats (having two children, the amount of this subsidy gave about $8-10 \%$ of the flat's purchase price), and it was not granted for the construction of family houses. Until 1988, the amount of long-term loans that could be received for the construction of family houses was also lower than for the private flats. In addition to that, the repayment period was shorter, and the rate of interest higher, though it was still lower than the real interest rate. Another type of strong negative preferencies was cused by the fact, that the amount of loans that could be drawn was bigger in the town than in the villages.

When investigating the construction of private flats we find, that in Budapest, the number of private flats in multi-story blocks of flats was three-times higher than that of the family

"(This is a kind of quasi-market type housing.) 
houses, while it was 1.5 -times higher in other towns, and only one-tenth in villages. State budget, and state housing policy subsidized the capital city and the large towns both in the construction of state housing and private housing, and the village-dwellers were left alone with their housing problems. In the development of infrastructure, similar aspects and proportions prevailed as in housing construction. All the above were, naturally, supported by ideological arguments, stating the superiority of the working class to peasantry, and the bigger importance of towns to villages. These, however, did not decrease the expectations of people to housing, and the lack of proper housing was reproduced by those who moved into the towns due to these problems. Besides the attitude resulting from the ideology, we are faced with the successful lobbying of the construction industry and the factories manufacturing pre-fabricated elements. Multi-story blocks of privatee flats could only be constructed by state companies, and this way these companies could build concentrated urban housing estates favourable for them so that their extremely high costs and poor-quality performance was always covered by the state budget. Finally, state subsidy of private housing ended its way at the state construction industry and the background industries.

Regional characteristics of housing construction show, that this is the population of the basically agricultural Great Hungarian Plain, where there are very few towns, which used their own resources at the housing constructions to the highest extent to the disadvantage of their consumption and savings. The debts of people living in this region are the biggest, while their incomes lag far behind the average of other regions. In addition to this, family houses, as a form of real-estate savings, are highly devaluated by the housing market these days, because the vast majority of necessary infrastructure is missing.

State housing constructed earlier will sell the majority of them to their actual inhabitants. However, as a consequence of disproportional housing constructions, there is hardly any state housing in the smaller towns and villages: there is not enough state housing to satisfy the socially needy people, how could there be enough for sale, thus increasing the incomes of the local governments. As a conclusion we can draw, that the changes in the political system preserved the previous privileges in the ownership of flats/houses and increased further the differences between the towns and villages. The lack of social housing in the villages forces the poor, deprivated people to the towns, who increase urban problems and thus create another ,,catch 22".

Transl. J. Mészáros



